\title{
Wrapping up the bad news - HIV assembly and release
}

\author{
Bo Meng and Andrew ML Lever
}

\begin{abstract}
The late Nobel Laureate Sir Peter Medawar once memorably described viruses as 'bad news wrapped in protein'. Virus assembly in HIV is a remarkably well coordinated process in which the virus achieves extracellular budding using primarily intracellular budding machinery and also the unusual phenomenon of export from the cell of an RNA. Recruitment of the ESCRT system by HIV is one of the best documented examples of the comprehensive way in which a virus hijacks a normal cellular process. This review is a summary of our current understanding of the budding process of HIV, from genomic RNA capture through budding and on to viral maturation, but centering on the proteins of the ESCRT pathway and highlighting some recent advances in our understanding of the cellular components involved and the complex interplay between the Gag protein and the genomic RNA.
\end{abstract}

Keywords: HIV, Budding, Assembly, ESCRT, ALIX, NEDD

\section{Review}

It is now over 20 years since the first striking pictures of a failure in the terminal budding process of HIV were published [1]. It took over three years for the findings to be confirmed and validated [2], and this marked the beginning of our understanding of the role of the ESCRT (endosomal sorting complex required for transport) system in the budding of HIV and subsequently in other enveloped viruses. Insights gained from HIV have revealed a wealth of details about normal cellular processes involving the ESCRT proteins, including vesicle budding into endosomal compartments called multi-vesicular bodies (MVB) [3] and the later discovery of the involvement of this process in the terminal events of cell division and cell separation [4]. How ESCRT functions in viral budding in HIV is now understood in remarkable detail; however, there are some notable unanswered questions.

Viral assembly is focused around the major structural protein of the virus capsid - Gag - which is a $55 \mathrm{kDa}$ polyprotein comprising four major subdomains - Matrix (MA), Capsid (CA), Nucleocapsid (NC) and p6. Flanking $\mathrm{NC}$ are two small 'spacer' peptides SP1 (p2) and SP2 (p1). The assembly of capsid like particles in HIV and other retroviruses can be achieved by the viral Gag pro-

\footnotetext{
* Correspondence: aml11@medschl.cam.ac.uk

Department of Medicine, University of Cambridge, Addenbrooke's Hospital, Cambridge CB2 0QQ, United Kingdom
}

tein independently of the presence of any cellular factors [5], and indeed conical structures resembling mature cores can also be formed [6,7], although production of spherical particles is optimized by nucleic acid. Authentic 'extended' Gag assemblies with dimensions comparable to a wild type viral capsid can be formed in the presence of lipid membranes and nucleic acid [8]. The NC region of Gag is well established as contributing to Gag assembly probably by 'bridging' between individual Gag monomers via genomic RNA (gRNA) [9]. Assembly of viable virus is possible using a minority of $\mathrm{NC}$ mutated Gag proteins containing intact late domains (see below) complemented by at least a fivefold excess of Gags with intact NC domains containing a late domain mutation [10], again inferring an important role for RNA binding to the NC domain inducing bridging. Despite the intimate interactions between Gag and RNA preceding and following the virus assembly, RNA in general and specifically the gRNA which is captured and packaged specifically by the viral Gag protein appeared until recently [11] to have no identified role in the ESCRT mediated process of viral assembly. The second conundrum is that whereas in MVB generation, sequential linking of ESCRT-0, I, II and III is essential, in HIV budding it is still unclear how ESCRT-I activates ESCRT-III given the apparent lack of requirement of ESCRT-II for successful budding in HIV [12]. This 
question has, again very recently, been opened up by some striking in vitro assembly studies where ESCRT-II does appear to be an integral part of the Gag budding process [13].

This review is a summary of our current understanding of the budding process of HIV, centering on the proteins of the ESCRT pathway. However, although that is probably the most intensively investigated and documented period in the virus export pathway, it is important to put it in the context of the processes that precede and follow it, but also overlap with it, namely trafficking and assembly, and release and maturation.

\section{Events preceding viral assembly and budding}

The earliest cytoplasmic stages of viral nucleocapsid assembly occur at the free cytoplasmic pool of translating ribosomes where unspliced viral RNA is translated to produce Gag (Figure 1A), and a subpopulation of Gag/Pol proteins are generated through a frameshift event. Gag is translated from the RNA species that also functions as the RNA genome. Once translated, the viral gRNA is trafficked away from the translating pool [14]. Although translation may not be a prerequisite for RNA capture [15], subsequent data have reinforced a predominantly cotranslational capture mechanism in HIV-1 [16,17] as shown previously for HIV-2 [18]. The uncleaved Gag polyprotein is involved in RNA genome capture, and the interaction of this with the viral RNA packaging signal $[19,20]$ has been shown in HIV-1 to be biophysically a very different process from that of interaction with the NC subfragment of Gag [21]. The latter, however, after cleavage from the precursor protein, is a powerful facilitator of nucleic acid interactions such as those involved in genome dimerization [22,23] and reverse transcription [24-27].

Following capture, evidence suggests that a small number of Gag proteins accompany the gRNA to the budding site at the plasma membrane [28-30]. Currently there is still a relative paucity of knowledge regarding the cellular components of the trafficking Gag/gRNA nucleoprotein complex. UPF1 is suggested to be involved in RNA stabilization [31] in association with UPF3b and Staufen. The cellular ATPase ABCE1 is also implicated in viral assembly in an RNA independent manner [32] and together with DDX6 and other processing body proteins (PBP) facilitate Gag multimerization [33]. The trafficking protein KIF-4 binds Gag [34], but whether this is a requirement for Gag/gRNA complex recruitment at the plasma membrane is unclear. Binding to the clathrin associated adaptor proteins AP-2 and AP-3 has been documented [35,36]; however, the sequential involvement of all these proteins in the Gag/gRNA nucleoprotein complex during its trafficking through the cell is still obscure. In Drosophila the RNA chaperone Staufen and ESCRT proteins interact with RNA [37,38] and influence its directional subcellular trafficking. There is also growing evidence that association of Gag with RNA is important for the directional trafficking of the complex [39]. Staufen has also been implicated in HIV-1 assembly [40,41], but evidence of a close mechanistic link between these factors in HIV-1 assembly is lacking.

Gag binds the viral RNA through interactions involving the $\mathrm{NC}$ domain of the polyprotein which itself contributes specificity of RNA selection [42]. RNA also binds non-specifically to a highly basic region of the MA domain reducing non-specific binding to lipid membranes [43] and increasing the specificity of MA for lipid membranes containing phosphatidylinositol (4.5) diphosphate (PIP2) [8] such as the plasma membrane. A saturated lipid myristic acid covalently linked to the $\mathrm{N}$-terminal region of Gag is sequestered in a hydrophobic pocket at the $\mathrm{N}$ terminus of MA and can be ejected by $\mathrm{pH}$ changes [44], the so called 'myristyl switch' mechanism [45]. This conformational change can also be evoked by PIP2 [46]. A model has been proposed whereby Gag bound to RNA through both MA and NC arrives at the plasma membrane where the presence of PIP2 and the effect of Gag multimerization displaces the RNA from the MA region and unleashes the myristic acid to provide a double anchor to the plasma membrane consisting of both myristate and PIP2 [46].

There is an estimated 5000 Gag proteins in the immature virion which are reduced to around 1500 in the mature particle [47], and yet relatively few escort the gRNA to the budding site. Possibly other nucleic acid molecules fulfill the gRNA role in masking the highly basic MA domain and favoring plasma membrane binding over other cellular membranes in the remainder of the Gag monomers that congregate there.

\section{The viral budding process \\ Viral late domains}

The essential role of late $(\mathrm{L})$ domains in retrovirus budding first came to attention from the observation of a failure to complete budding seen in deletion and mutation of the terminal component of the HIV-1 Gag polyprotein p6 [1,2]. Two late domains have subsequently been identified within the p6 region of the HIV-1 Gag: the PTAP and YPXnL (where $\mathrm{X}$ refers any amino acid and $\mathrm{n}=1 \sim 3$ residues) motifs (Figure 1B). PTAP was noted to be conserved in HIV-1 and HIV-2 and other retroviruses and was later identified in members of the Filoviridae, Arenaviridae and Hepeviridae families $[48,49]$. PTAP-TSG101 interaction was originally identified by yeast two hybrid studies [50,51]. Functional analyses of disrupting this interaction by siRNA [50], mutagenesis [52], or trans dominant inhibition by TSG101 fragments [53] recapitulates classic phenotype of L-domain-defective HIV. 


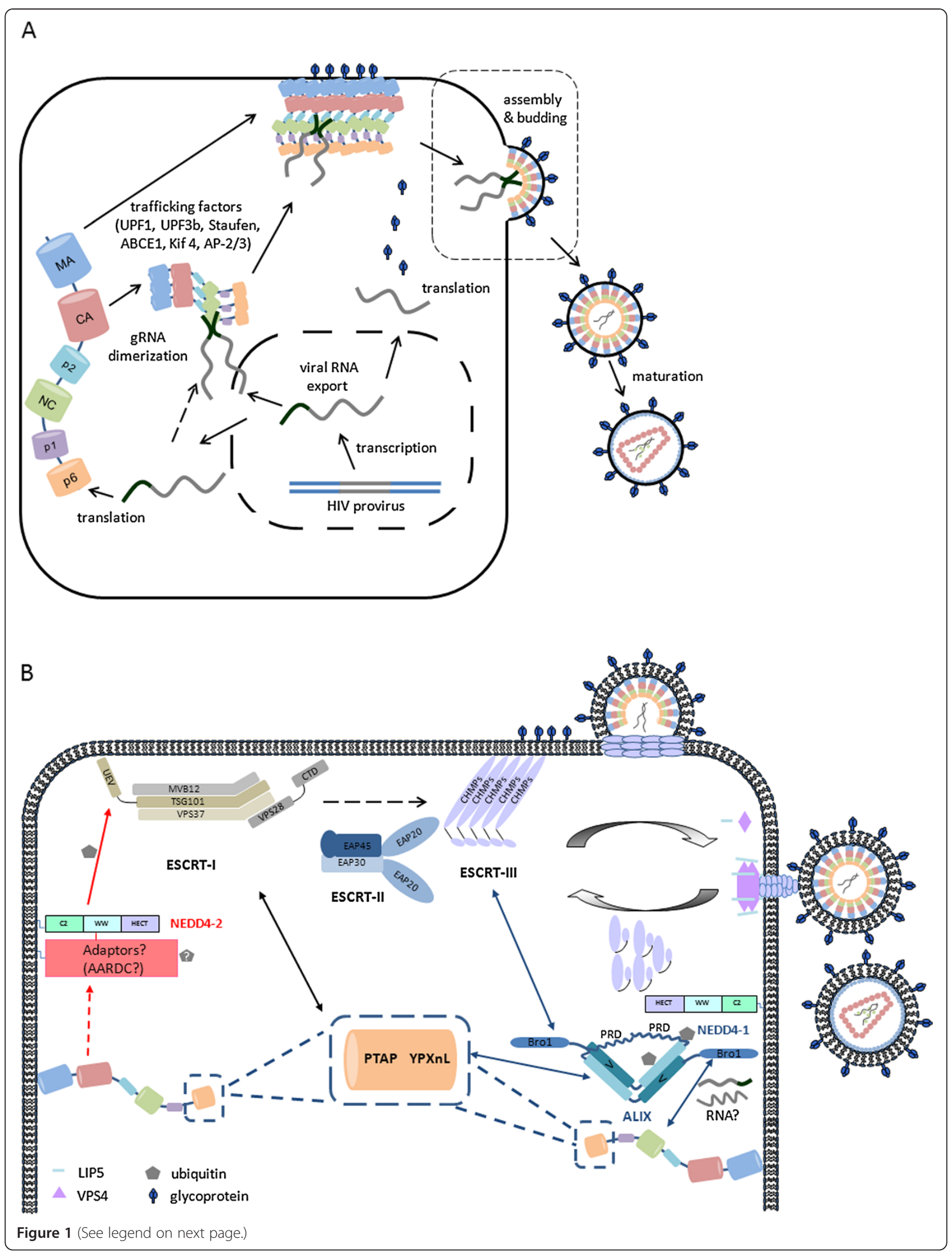


(See figure on previous page.)

Figure 1 Diagrammatic overview of the late stages of the HIV life-cycle. (A) After transcription the full length viral RNA is exported from the nucleus to the cytoplasm for Gag (and Gag-Pol) synthesis. Singly spliced RNA is exported to produce the envelope glycoproteins (dark blue). Gag binds to a dimeric genomic RNA via its NC domain to form ribonucleoprotein complex which is trafficked to the membrane where more Gag assembles and budding occurs (black dashed-box and B). During HIV particle assembly or soon after particle release, protease (PR, not shown) cleaves the Gag polyprotein to MA, CA and NC and protein rearrangement occurs to form the mature virion. (B) Close-up view of the HIV budding process. ESCRT-I is recruited to the budding site via interactions between PTAP in p6 of Gag and TSG101 of ESCRT-I (black arrow). The link to ESCRT-III (CHMPs) for budding is via an unknown mechanism but seems to bypass ESCRT-II (black dashed-arrow). Additionally/alternatively, ALIX binds to YPXnL motif also in p6 and NC via $V$ and Bro1 domain, respectively and directs Gag to ESCRT-III via its Bro1 domain for budding (blue arrow). RNA involvement in NC-ALIX binding has been suggested (wavy line), but the identity of the RNA is not clear. HIV has no PPXY motif, but the NEDD4-like ubiquitin ligase family has also been implicated in facilitating HIV joining the ESCRT pathway for budding probably via adaptors on the plasma membrane (NEDD4-2; red arrow) or the ALIX pathway (NEDD4-1). For membrane scission to occur, ESCRT-III components are activated and polymerized to form a dome-shaped structure. VPS4, regulated by LIP5-CHMP5 and CHMP1-ISTI binary complexes (not shown), is recruited to the budding site where it multimerizes to form a dodecamer and disassembles the ESCRT-III filaments for recycling. How membrane scission occurs is unknown.

The YPXnL late domain was first identified in the equivalently sited p9 of EIAV (equine infectious anemia virus) Gag [54] and subsequently in p6 of HIV-1 Gag [55] and p2b of RSV (Rous sarcoma virus) Gag [56]. It promotes budding by binding to ALIX (apoptosis-linked gene 2-interacting protein X), an associated protein of the ESCRT pathway; although the binding affinity of ALIX to the YPXnL motif in HIV-1 is lower than to the corresponding EIAV region [57].

Other retroviruses, including murine leukemia virus (MLV) [58,59], RSV [60-62], Mason-Pfizer monkey virus (M-PMV) [63,64], and Human T-cell leukemia/lymphoma virus type 1 (HTLV-1) [65-67], use a PPXY late domain (where $X$ refers any amino acid) for virus budding. The PPXY late domain was first described in the Gag region of RSV [61] and has since been identified in different virus family members of the Filoviridae, Arenaviridae and Rhabdoviridae [48]. These motifs bind to the WW domain of NEDD-like HECT ubiquitin ligases [68]. The link between the PPXY late domain and the ESCRT pathway is unknown. However, it has been suggested in HIV that NEDD-like ligase either ubiquitinates and activates ESCRT-I [69], or interacts with ALIX to function in virus release [70]. Central to the function of the late domains are the proteins of the ESCRT pathway.

\section{ESCRT proteins}

The ESCRT system, first elucidated in yeast [71,72], consists of four sets of different cellular proteins (ESCRT-0, I, II and III) that are recruited sequentially to endosomal membranes for biogenesis of MVBs and sorting of the ubiquitinated cargos into those vesicles [73]. Additionally, members of ESCRT or ESCRT-associated proteins are involved in cytokinesis [74], microvesical shedding [75], exosome biogenesis [76] and ubiquitination-independent endosomal sorting [77].

\section{ESCRT-O}

ESCRT-0 comprises two components STAM (signal transducing adaptor molecule) and HRS (hepatocyte growth factor (HGF)-regulated tyrosine kinase substrate) in humans (Vps27 and Hse1 are the homologues in yeast) and is the least conserved part of the ESCRT pathway. ESCRT-0 is essential for recognition of ubiquitinated cargos at the endosomal membrane and HRS interacts with TSG101 of ESCRT-I to cascade the sorting of cargos and MVB formation. Despite the apparent lack of requirement of HRS for HIV budding [78], a genomewide screen has identified HRS as a host factor required for HIV infection [79] subsequently confirmed by an siRNA knockdown study which reduced HIV release to less than $10 \%$ of wild type (wt) levels [80]. The phenotype is distinct from classic ESCRT related budding defects [50]. Depletion of HRS arrests HIV-1 particles at the cell surface and in endosomes in a similar manner to that seen in the BST-2 expressing cells infected with Vpu-defective HIV-1 [81]. Further analysis has shown that HRS is required for efficient HIV-1 release by facilitating Vpu-induced BST-2 downregulation and degradation [80].

\section{ESCRT-I}

ESCRT-I includes TSG101 [50,82], VPS28 [83-85], one copy of one of the four versions of VPS37 (A-D) [86-88] and one of the two versions of MVB12 (A\&B) $[84,89,90]$ in a stoichiometry of 1:1:1:1 [84,89,91]. The budding of HIV requires the intact ESCRT-I, although the involvement of VPS37A and VPS37D in this process have not been reported. Human ubiquitin associated protein-1 (UBAP-1) is the newly identified member of ESCRT-I [92] involved solely in ubiquitinated endosomal cargo degradation but not in HIV budding or midbody abscission $[93,94]$. The heterotetrameric complex of ESCRT-I in yeast consists of a globular headpiece with all four components (Vps23, Vps28, Vps37, and Mvb12; orthologs 
respectively of TSG101, VPS28, VPS37, and MVB12 in humans) attached to an extended stalk composing Vps23, Vps37 and Mvb12 [84].

The human HRS protein from ESCRT-0 recruits TSG101 by binding to its UEV (ubiquitin E2 variant) domain [78]. Hence it was proposed that Gag could mimic this TSG101 recruiting ability by directly interacting with UEV. Indeed structural studies of the UEV domain in complex with the late domain PTAP motif has shown the PTAP peptide binds UEV in a bifurcated groove above the inactive enzymatic site [95]. This was further supported by the demonstration that a PTAP budding defect could be rescued when an HRS TSG101 binding fragment is fused to a PTAP L domain-deleted Gag [78]. Very recently, Nabhan et al. proposed that in order to mediate virus budding from host cells HIV Gag (and likely other viral proteins) alternatively have evolved to mimic arrestin domain containing protein-1 (ARRDC1)-mediated ARRDC related microvesicle (ARMMs) release where both TSG101 and VPS4 (AAA ATPase for disassembling the ESCRT-III and see below) are required [75]. ARRDC1 is directed to the plasma membrane by its arrestindomain and has been previously implicated in functioning as an adaptor in PPXY-dependent budding [96].

Disruption of VPS28 binding to TSG101 causes the arrest of HIV budding suggesting VPS28 plays an integral role in this process $[87,97]$. The C-terminal domain of VPS28 binds to the ESCRT-II complex [98], and fusion of this region to Gag late domain deletion construct rescues an EIAV budding defect [85]. Additionally, VPS37B and $C$ can rescue a late domain budding defect when fused to the PTAP late domain deficient Gag, consistent with the notion that VPS37 is also part of ESCRT-I and involved in virus budding $[87,88]$. MVB12 appears to be the exception in that the budding process is not affected when it is depleted [89], but both depletion and overexpression of MVB12 reduce virus infectivity.

\section{ESCRT-II}

ESCRT-II forms as a 'Y' shaped heterotetramer including two copies of Vps25/EAP20, one each of Vps22/EAP30 and Vps36/EAP45 [99]. In yeast, ESCRT-II physically bridges the ESCRT-I and ESCRT-III complexes and is essential for MVB protein sorting and vesicle formation [100-102]. In humans, the interaction between ESCRT-I and ESCRT-II is slightly different due to the lack of an NZF (Npl4-type zinc-finger) motif, which forms the interface in the ESCRT-I/ESCRT-II complex in yeast [101,103]. The interaction between ESCRT-II and ESCRT-III, however, is similar to that in yeast $[99,100]$.

Using purified yeast ESCRT components with giant unilamellar vesicles (GUV), Wollert and Hurley [102] demonstrated that ESCRT-0 clusters ubiquitinated cargo on the membrane, and ESCRT-I together with ESCRT-II deform the membrane where the cargo is encapsulated. Both ESCRT-I and II are found on the outside of the bud where the ESCRT-III is recruited to cleave the bud to form the intralumenal vesicles. However, a role for ESCRT-II in HIV budding was not clear until this same group recently demonstrated that in the GUV system ESCRT-II is indeed recruited and co-localized with ESCRT-I on the Gag assembly site [13]. This is in marked contrast to evidence from siRNA knock down studies in vivo [12] which suggest that ESCRT-II is dispensable. This apparent discrepancy is puzzling but may be due to incomplete protein depletion by siRNA if only a small amount of ESCRT-II is needed for HIV-1 budding. Alternatively there may be some unknown additional pathway bridging ESCRT-I and -III in vivo.

\section{ESCRT-III}

The core structure of ESCRT-III includes 12 members of the charged multivesicular protein (CHMP) family (CHMP1A, 1B, 2A, 2B, 3, 4A-C, 5, 6, 7 and IST1). Structural studies of some of the CHMP proteins have shown that they share an N-terminal 4-helix-bundle core structure mediating membrane binding and filament formation [104-106]. The C-terminal tail is adapted as in either auto-inhibition status by folding back on the core or in an activated position for oligomerization [104,107] and also contains MIM (MIT (microtubule-interacting and transport) domain interacting motif) sequence(s) that interacts with MIT-containing proteins in a versatile fashion [108-114]. The involvement of ESCRT-III in retroviral budding was originally suggested from studies of a dominant-negative VPS4 which demonstrated a late domain deficient HIV budding phenotype [50,115]. Later certain CHMP members were also shown to have similar effects when overexpressed as fusion isoforms $[55,116,117]$. More recently, it was shown that introducing certain mutations in the ALIX/CHMP4 binding site can abolish ALIXmediated budding $[118,119]$ confirming the integral role of ESCRT-III during the budding process. Triggering of ESCRT-III can potentially be achieved by Vps36/EAP45 binding to CHMP6 [117]; VPS28 binding to CHMP6 [85] or via the associated protein ALIX, which binds to TSG101 and CHMP4 [118,119].

In yeast, Vps20/CHMP6, Snf7/CHMP4, Vps24/CHMP3 and Vps2/CHMP2 are sequentially recruited to the membrane and deform the membrane in vitro [120]. Vps 20 plays an important role in bridging with Vps 25 of ESCRT-II and triggering the polymerization of Snf7 [121], although it is not required in HIV budding in vivo [12,122]. ALIX may provide an alternative route by linking CHMP4 of ESCRT-III [123]. Alternatively, it is also possible that other undefined host factor(s) exist that fulfil the link between Gag and budding. 
Despite the evidence of sequential recruitment of CHMP in yeast, in vivo depletion studies in mammalian cells have shown that only CHMP2 \& 4 are involved in HIV budding [122], although new findings have suggested CHMP3 also plays a synergistic role with CHMP2 [124]. In contrast to those in vivo studies, recent in vitro reconstitution in GUV using purified ESCRT complex and HIV Gag has demonstrated that the co-localization of CHMP4 with Gag is maximal only in the presence of CHMP6 and other upstream ESCRT complexes implying the HIV budding route is analogous to that of MVB formation in yeast [13]. Although the exact involvement of some of the individual CHMP proteins is not yet certain, CHMP4 in budding formation is confirmed in both in vitro reconstitution $[102,125]$ and in vivo studies $[122,126]$.

Once CHMP protein is activated and recruited to the membrane, it is thought to oligomerize. Indeed, several studies have demonstrated that CHMP proteins can form filaments [104,126-129], and it has been hypothesized that the formation of such filament would deform the membrane. This, together with oligomerized and activated VPS4, may ultimately provide sufficient force for scission to occur, although VPS4 independent budding is also documented [102,125]. Interestingly, observation of such polymerized CHMP proteins in vivo has largely been unsuccessful apart from overexpression of CHMP4 [126] and CHMP2B [129].

Vta1/LIP5, Did2/CHMP1, Ist1/IST1 and Vps60/CHMP5 regulate and recruit VPS4 to the budding site [107,130-135]. VPS4 exists as a single isoform in yeast but is present as two isoforms in humans (VPS4/SKD1A\&B) [136]. It contains an N-terminal MIT domain, a link segment and a single ATPase cassette. MIT domain binds to MIM1 $[109,113]$ and MIM2 $[108,110]$ of subset of CHMP proteins and both MIM1\&2 binding sites are required for recruiting VPS4A to endosomal membrane and VPS4B for HIV budding [108]. VPS4 exists as a catalytically inactive dimeric form in the cytoplasm but once recruited to the membrane-associated ESCRT-III, it forms a catalytically active dodecamer $[115,137]$. ESCRT-associated protein LIP5 is believed to play an important regulatory role in VPS4 oligomerization [138]. It functions by bridging VPS4 through VSL (Vta1/SBP1/LIP5) domain and ESCRT-III by its tandem MIT domains located at the $\mathrm{N}$ terminus $[111,138,139]$. Given the regulatory role of LIP5 in VPS4 oligomerization, it is probably not surprising that depletion of LIP5 also decreased HIV budding [134]. The formation of dodecamer complexes of VPS4 disassemble ESCRT-III through an ATP-driven process which is poorly defined. However, from the nature of VPS4 as an AAA-type ATPase, it has been suggested that ESCRT-III is engaged by passing through the central pole of VPS4 dodecamers [140,141].
Investigation of how membrane scission occurs is still an area of great interest. Several schools of thoughts exist. One model suggests that the depolymerization on ESCRT-III filaments by VPS4 provides enough force to the underlying membrane for scission to occur [120]. It has been shown microscopically that VPS4 is recruited to the membrane abscission site during cytokinesis [142] and retrovirus budding $[143,144]$ before the cleavage occurs supporting the notion that VPS4 may provide the constriction for membrane scission. However, VPS4 independent membrane scission has also been observed in vitro [102,125]. Other membrane scission models have also been proposed. Based on the observations that various members of ESCRT-III can form a filamentous structure in vitro $[104,127,128]$ and in vivo $[126,129]$, it was proposed that the progression of this filament would lead to thinning of the plasma membrane and to a certain degree the energy accumulated would favor fission [145]. Recent studies have suggested that CHMP4 polymerization is regulated by $\mathrm{CC} 2 \mathrm{D} 1 \mathrm{~A}$ and $\mathrm{CC} 2 \mathrm{D} 1 \mathrm{~B}$ since when CC2D1A is overexpressed HIV budding is inhibited and conversely if CC2D1 is depleted HIV budding is enhanced [146,147]. A further alternative has recently been proposed suggesting that individual ESCRT-III filaments are sufficient to promote the scission [148]. This model is based on the observation that Vps32/CHMP4 is recruited by ESCRT-II and the Vps20/CHMP6 complex to the curvature region of the membrane and as such modulates the mobility of the membrane. It was proposed that when the binding energy between ESCRT-III filament and membrane exceeds the energy barrier to scission, vesicles would more likely to be pinched off from the membrane.

\section{ALIX}

ALIX is a mammalian homologue of Brol in yeast, originally identified as a member of class E VPS class genes from yeast [149]. Subsequently, HIV has also been shown to be able to utilize ALIX to bud from the cells, although this pathway appears to be subordinate to the ESCRT-I route $[118,150]$. Unlike the classical ESCRT pathway where ESCRT-I and -III in conjunction with a PTAP late domain are involved in virus budding, ALIX-mediated budding relies on the interaction with a different late domain, YPXnL, which is also located within the $\mathrm{p} 6$ region of Gag in HIV-1. No YPXnL-domain-containing cellular proteins had been identified in vivo until recently when it was shown that ALIX binds to syntenin, functioning in exosome biogenesis [76] and protease-activated receptor 1 (PAR1) for ubiquitination-independent endosomal cargo sorting [77].

ALIX contains an effector $\mathrm{V}$ domain for binding to the YPXnL motif $[118,151]$ and polyubiquitin [152]. This is flanked by an $\mathrm{N}$ terminus Brol domain and a prolinerich C-terminal domain (PRD). The PRD also binds to 
TSG101, endophilin CIN85 and ALG-2 [153,154]. Although both monomers and dimers were seen $[118,155]$, the active conformation of ALIX is a dimer [123,156,157]. The ALIX pathway was first discovered in studies using a Gag that lacked a functional TSG101-binding site $[55,117]$. It was shown that, when overexpressed, ALIX rescued the budding defect and this rescue is fully dependent on the YPXnL late domain $[118,119]$ and intact polyubiquitin binding sites on V domain [152]. In addition, structural and biochemical analyses of an ALIX homologue in yeast [158] or ALIX itself $[118,119,159]$ have shown that mutating some residues in the hydrophobic patch of Bro 1 domain abolishes its interaction with CHMP4 and as such eliminates its ability to rescue the budding defect. Interestingly, when overexpressed, Bro 1 rescues the release of HIV-1 lacking both PTAP and YPXnL motifs [160]. Functional analysis has shown that ALIX mediated rescue also requires the NC domain in Gag [160,161]. The interaction between ALIX and the NC domain was documented as being insensitive to benzonase [161], a powerful nuclease. However, very recent data suggest that the interaction between the NC domain of Gag and the Brol domain of ALIX is RNA dependent [11], although there was no evidence that it was specific for viral RNA. If the latter is validated it would in part answer the question as to the involvement of RNA in this stage of the assembly process. The C-terminal PRD domain is also essential for rescuing ALIX mediated virus budding, although the binding sites with TSG101, endophilin, CIN85 and CMS are dispensable for the function of ALIX in HIV-1 budding [118,119]. The PRD domain also regulates the ALIX function by folding back against the upper domains and as such autoinhibits YPXnL late domain binding site on the $\mathrm{V}$ domain $[157,162,163]$.

\section{NEDD4-like ubiquitin ligases}

There are several members of the NEDD-like ubiquitin ligase family. They all contain an $\mathrm{N}$ terminus $\mathrm{C} 2$ domain for membrane binding [164], two to four WW (Trp-Trp) substrate-binding domains and a C-terminal HECT (homologous with the E6-associated protein C-terminus) catalytic domain for targeting ubiquitination. The PPXY late domain was first described in the Gag protein of RSV $[60,62]$, which functions by binding to the WW domain of NEDD-like HECT ubiquitin ligases. Despite the lack of a PPXY late domain in HIV-1, overexpression of NEDD4-1 or 4-2 nevertheless stimulates the PTAP late domain mutant defective budding $[69,70]$. Interestingly, the most potent effector in rescuing the budding defect is NEDD4$2 \mathrm{~s} / \triangle \mathrm{C} 2$ [165], a natural isoform of NEDD4-2 in which most of the C2 domain is truncated [166]. Additionally, neither the PTAP nor the YPXnL domain is required for NEDD4-2s mediated budding $[69,165]$. To confer a rescue effect, NEDD4-2s must be catalytically active suggesting ubiquitination of viral or cellular proteins is needed $[69,165]$. The remaining C2 domain is also important in binding to Gag and itself is sufficient to confer HIV-1 budding ability on various members of NEDD family [167]. Depletion of TSG101 abrogates the NEDD4-2s mediated remediation of budding defect, suggesting that ESCRT-I is recruited in this process [69]. Like NEDD4-2, NEDD4-1 can also rescue the PTAP late domain budding defect, albeit less efficiently than NEDD4-2 [69,70]. Additionally, the effect of NEDD4-1 on budding functions in a different manner that is independent of cellular TSG101 and requires the YPXnL late domain. This implies that ALIX recruits NEDD4-1 to mediate HIV budding through the YPXnL-ALIX budding pathway [70].

\section{Post budding Gag processing}

Formation of the budded particle and final scission from the cell is associated with the processes of proteolytic processing of the Gag polyprotein into its component fragments, morphogenesis of the spherical particle into the MA lined enveloped virion with the conical core and maturation of the loosely associated paired RNA genomes into a mature tightly linked dimer. Genomic RNA has been suggested in the past to have a structural scaffolding role aiding viral assembly $[6,168,169]$ and even trace amounts of nucleic acid appear to enhance in vitro assembly. Gag dimerization has been implicated as an important first step [170,171]. Mutations that disrupt the dimer interface between the CA domains prevent correct assembly [172]; a plausible role for the gRNA is that it also helps to bridge Gag dimers [173]. The MA and CA domains of Gag foster formation of hexameric arrays of the polyprotein but during cleavage the N-terminal domain of CA can form both pentamers and hexamers and it is this that generates the steric capability to form the asymmetric fullerene cone of the mature capsid [7,174-176].

Release of the homodimeric aspartyl protease (PRO) from Gag/Pol is initiated in an as yet obscure manner although there is evidence for the involvement of clathrin $[177,178]$, but once this has begun autocatalytic cleavage of the remaining Gag and Gag/Pol proteins can occur. Proteolytic cleavage of the Gag and Gag/Pol polyproteins by the viral protease is associated with an alteration in the nature of the dimer interaction from rather loosely associated molecules to a tight dimer. It has become apparent that all these processes are closely interconnected [179-181]. In HIV-2, it has been shown that the proteolytic cleavage of Gag and the packaging of dimeric RNA are intimately inter-dependent [180]; failure of RNA dimerization leads to aberrant proteolytic cleavage of Gag. The reason for this is not clear but it may be due to the lack of an RNA scaffold in bringing together two protease monomers within two $\mathrm{Gag} / \mathrm{Pol}$ polyproteins 
and facilitating cleavage at the correct rate and site. Conversely, it has been known for a considerable time that a protease deficient HIV produces poorly dimeric RNA genomes [23] and the mis-processing of HIV-2 Gag was shown to correct in long-term culture by reversion mutation in the MA portion of Gag and this unexpectedly, despite the persistence of the RNA dimer mutation, led to a return of packaging wt levels of dimeric RNA [180]. Similar reversion mutations in the HIV-1 Gag have been seen which restore replication to dimer mutants [182] although the analysis did not reveal whether the RNA dimerization mutation had been left unchanged or RNA dimer packaging had been restored.

\section{Conclusions}

Despite remarkable progress in understanding this intimate interaction between the virus and the cell in which results in viral egress, the late stage of the viral life cycle is still a patchwork of areas of better and less well understood steps. At present it resembles a jigsaw puzzle with missing pieces. The central process of ESCRT mediated budding is fairly well established, but there are still controversies; and the significance of the recently identified variants of some of the ESCRT components is still unclear. The roles of gRNA, in assembling what is primarily a nucleoprotein complex, are only just beginning to be understood. There are gaps in our understanding of the connection of gRNA capture to budding although interdependencies between RNA and protein processing are beginning to emerge. Understanding the assembly process is critically important not least because the diverse interactions with cellular components are promising drug targets since the scope for viral mutational escape is limited due to the unchanging nature of the essential cellular factors involved. More work is needed to fill in the missing links in this remarkable process and to identify susceptible areas for therapeutic intervention.

\footnotetext{
Abbreviations

HIV: Human immunodeficiency virus; EIAV: Equine infectious anemia virus; MLV: Murine leukemia virus; RSV: Rous sarcoma virus; M-PMV: Mason-Pfizer monkey virus; HTLV-1: Human T-cell leukemia/lymphoma virus type 1; ESCRT: Endosomal sorting complex required for transport; MVB: Multivesicular bodies; TSG101: Tumour susceptibility gene 101 CHMP: Charged multivesicular body proteins; GUV: Giant unilamellar vesicles; NEDD: Neural precursor cell expressed developmentally down-regulated protein; HECT: Homologous with E6-associated protein C-terminus; VPS: Vacuolar protein sorting; ALIX: Apoptosis-linked gene 2-interacting protein $X_{;}$HGS: Hepatocyte growth factor-regulated tyrosine kinase substrate; STAM: Signal transducing adaptor molecule; MIT: Microtubule-interacting and transport molecules; MIM: MIT domain interacting motifs; ARRDC 1: Arrestin domain-containing protein 1; ARMM: ARRDC1-mediated microvesicles; HRS: hepatocyte growth factor (HGF)-regulated tyrkinase substrate; NZF: Npl4-type zinc-finger; IST-1: Increased sodium tolerance-1; CIN85: Cbl-interacting protein of $85 \mathrm{kDa}$; EAP: ELL-associated proteins.
}

\section{Competing interests}

The authors declare they have no competing interests.
Authors' contributions

$\mathrm{BM}$ and $\mathrm{AL}$ both wrote the manuscript. Both authors read and approved the final manuscript.

Received: 23 August 2012 Accepted: 21 December 2012

Published: 10 January 2013

\section{References}

1. Gottlinger HG, Dorfman T, Sodroski JG, Haseltine WA: Effect of mutations affecting the $\mathrm{p} 6$ gag protein on human immunodeficiency virus particle release. Proc Natl Acad Sci U S A 1991, 88:3195-3199.

2. Huang $M$, Orenstein JM, Martin MA, Freed EO: p6Gag is required for particle production from full-length human immunodeficiency virus type 1 molecular clones expressing protease. J Virol 1995, 69:6810-6818.

3. Wollert $\mathrm{T}$, Yang $\mathrm{D}$, Ren $\mathrm{X}$, Lee HH, Im YJ, Hurley JH: The ESCRT machinery at a glance. J Cell Sci 2009, 122:2163-2166.

4. Caballe A, Martin-Serrano J: ESCRT machinery and cytokinesis: the road to daughter cell separation. Traffic 2011, 12:1318-1326.

5. Campbell S, Vogt VM: Self-assembly in vitro of purified CA-NC proteins from Rous sarcoma virus and human immunodeficiency virus type 1 . J Virol 1995, 69:6487-6497.

6. Campbell S, Rein A: In vitro assembly properties of human immunodeficiency virus type $1 \mathrm{Gag}$ protein lacking the p6 domain. J Virol 1999, 73:2270-2279.

7. Ganser BK, Li S, Klishko WY, Finch JT, Sundquist WI: Assembly and analysis of conical models for the HIV-1 core. Science 1999, 283:80-83.

8. Datta SA, Heinrich F, Raghunandan S, Krueger S, Curtis JE, Rein A, Nanda H: HIV-1 Gag extension: conformational changes require simultaneous interaction with membrane and nucleic acid. J Mol Biol 2011, 406:205-214.

9. Hogue IB, Hoppe A, Ono A: Quantitative fluorescence resonance energy transfer microscopy analysis of the human immunodeficiency virus type 1 Gag-Gag interaction: relative contributions of the CA and NC domains and membrane binding. J Virol 2009, 83:7322-7336.

10. Nikolaitchik OA, Gorelick RJ, Leavitt MG, Pathak VK, Hu WS: Functional complementation of nucleocapsid and late domain PTAP mutants of human immunodeficiency virus type 1 during replication. Virology 2008, 375:539-549.

11. Sette $P$, Dussupt $V$, Bouamr F: Identification of the HIV-1 NC Binding Interface in Alix Bro1 Reveals a Role for RNA. J Virol 2012, 86:11608-11615.

12. Langelier C, von Schwedler UK, Fisher RD, De Domenico I, White PL, Hill CP, Kaplan J, Ward D, Sundquist WI: Human ESCRT-II complex and its role in human immunodeficiency virus type 1 release. J Virol 2006, 80:9465-9480.

13. Carlson LA, Hurley $\mathrm{JH}$ : In vitro reconstitution of the ordered assembly of the endosomal sorting complex required for transport at membranebound HIV-1 Gag clusters. Proc Natl Acad Sci U S A 2012, 109:16928-16933.

14. Dorman N, Lever A: Comparison of viral genomic RNA sorting mechanisms in human immunodeficiency virus type 1 (HIV-1), HIV-2, and Moloney murine leukemia virus. J Virol 2000, 74:11413-11417.

15. Butsch M, Boris-Lawrie $K$ : Translation is not required To generate virion precursor RNA in human immunodeficiency virus type 1-infected T cells. J Virol 2000, 74:11531-11537.

16. Poon DT, Chertova EN, Ott DE: Human immunodeficiency virus type 1 preferentially encapsidates genomic RNAs that encode Pr55(Gag): functional linkage between translation and RNA packaging. Virology 2002, 293:368-378.

17. Liang C, Hu J, Russell RS, Wainberg MA: Translation of Pr55(gag) augments packaging of human immunodeficiency virus type 1 RNA in a cis-acting manner. AIDS Res Hum Retroviruses 2002, 18:1117-1126.

18. Kaye JF, Lever AM: Human immunodeficiency virus types 1 and 2 differ in the predominant mechanism used for selection of genomic RNA for encapsidation. J Virol 1999, 73:3023-3031.

19. Lever AM: HIV-1 RNA packaging. Adv Pharmacol 2007, 55:1-32.

20. Lu K, Heng $X$, Summers MF: Structural determinants and mechanism of HIV-1 genome packaging. J Mol Biol 2011, 410:609-633.

21. Bell NM, Kenyon JC, Balasubramanian S, Lever AM: Comparative structural effects of HIV-1 Gag and nucleocapsid proteins in binding to and unwinding of the viral RNA packaging signal. Biochemistry 2012, 51:3162-3169.

22. Feng YX, Copeland TD, Henderson LE, Gorelick RJ, Bosche WJ, Levin JG, Rein A: HIV-1 nucleocapsid protein induces "maturation" of dimeric retroviral RNA in vitro. Proc Natl Acad Sci U S A 1996, 93:7577-7581 
23. Fu W, Gorelick RJ, Rein A: Characterization of human immunodeficiency virus type 1 dimeric RNA from wild-type and protease-defective virions. J Virol 1994, 68:5013-5018.

24. Druillennec S, Caneparo A, de Rocquigny H, Roques BP: Evidence of interactions between the nucleocapsid protein $\mathrm{NCp} 7$ and the reverse transcriptase of HIV-1. J Biol Chem 1999, 274:11283-11288.

25. Huang M, Zensen R, Cho M, Martin MA: Construction and characterization of a temperature-sensitive human immunodeficiency virus type reverse transcriptase mutant. J Virol 1998, 72:2047-2054.

26. Lener D, Tanchou V, Roques BP, Le Grice SF, Darlix JL: Involvement of HIV-I nucleocapsid protein in the recruitment of reverse transcriptase into nucleoprotein complexes formed in vitro. J Biol Chem 1998, 273:33781-33786.

27. Darlix JL, Godet J, Ivanyi-Nagy R, Fosse P, Mauffret O, Mely Y: Flexible nature and specific functions of the HIV-1 nucleocapsid protein. $J \mathrm{MO}$ Biol 2011, 410:565-581.

28. Jouvenet N, Bieniasz PD, Simon SM: Imaging the biogenesis of individual HIV-1 virions in live cells. Nature 2008, 454:236-240.

29. Jouvenet N, Simon SM, Bieniasz PD: Imaging the interaction of HIVgenomes and Gag during assembly of individual viral particles. Proc Natl Acad Sci U S A 2009, 106:19114-19119.

30. Kutluay SB, Bieniasz PD: Analysis of the initiating events in HIV-1 particle assembly and genome packaging. PLoS Pathog 2010, 6:e1001200.

31. Ajamian L, Abrahamyan L, Milev M, Ivanov PV, Kulozik AE, Gehring NH, Mouland AJ: Unexpected roles for UPF1 in HIV-1 RNA metabolism and translation. RNA 2008, 14:914-927.

32. Zimmerman C, Klein KC, Kiser PK, Singh AR, Firestein BL, Riba SC, Lingappa JR: Identification of a host protein essential for assembly of immature HIV-1 capsids. Nature 2002, 415:88-92.

33. Reed JC, Molter B, Geary CD, McNevin J, McElrath J, Giri S, Klein KC, Lingappa JR: HIV-1 Gag co-opts a cellular complex containing DDX6, a helicase that facilitates capsid assembly. J Cell Biol 2012, 198:439-456.

34. Tang Y, Winkler U, Freed EO, Torrey TA, Kim W, Li H, Goff SP, Morse HC: 3rd: Cellular motor protein KIF-4 associates with retroviral Gag. J Virol 1999, 73:10508-10513.

35. Dong X, Li H, Derdowski A, Ding L, Burnett A, Chen X, Peters TR, Dermody TS, Woodruff E, Wang JJ, Spearman P: AP-3 directs the intracellular trafficking of HIV-1 Gag and plays a key role in particle assembly. Cell 2005, 120:663-674.

36. Batonick M, Favre M, Boge M, Spearman P, Honing S, Thali M: Interaction of HIV-1 Gag with the clathrin-associated adaptor AP-2. Virology 2005, 342:190-200.

37. St Johnston D, Beuchle D, Nusslein-Volhard C: Staufen, a gene required to localize maternal RNAs in the Drosophila egg. Cell 1991, 66:51-63.

38. Irion $U$, St Johnston D: bicoid RNA localization requires specific binding of an endosomal sorting complex. Nature 2007, 445:554-558.

39. Sherer NM, Swanson CM, Papaioannou S, Malim MH: Matrix mediates the functional link between human immunodeficiency virus type 1 RNA nuclear export elements and the assembly competency of Gag in murine cells. J Virol 2009, 83:8525-8535.

40. Mouland AJ, Mercier J, Luo M, Bernier L, DesGroseillers L, Cohen EA: The double-stranded RNA-binding protein Staufen is incorporated in human immunodeficiency virus type 1: evidence for a role in genomic RNA encapsidation. J Virol 2000, 74:5441-5451.

41. Chatel-Chaix L, Clement JF, Martel C, Beriault V, Gatignol A, DesGroseillers L, Mouland AJ: Identification of Staufen in the human immunodeficiency virus type $1 \mathrm{Gag}$ ribonucleoprotein complex and a role in generating infectious viral particles. Mol Cell Biol 2004, 24:2637-2648.

42. Zhang $Y$, Barklis E: Nucleocapsid protein effects on the specificity of retrovirus RNA encapsidation. J Virol 1995, 69:5716-5722.

43. Chukkapalli V, Oh SJ, Ono A: Opposing mechanisms involving RNA and lipids regulate HIV-1 Gag membrane binding through the highly basic region of the matrix domain. Proc Natl Acad Sci U S A 2012, 107:1600-1605.

44. Tang C, Loeliger E, Luncsford P, Kinde I, Beckett D, Summers MF: Entropic switch regulates myristate exposure in the HIV-1 matrix protein. Proc Natl Acad Sci U S A 2004, 101:517-522.

45. Spearman $\mathrm{P}$, Horton $\mathrm{R}$, Ratner L, Kuli-Zade I: Membrane binding of human immunodeficiency virus type 1 matrix protein in vivo supports a conformational myristyl switch mechanism. J Virol 1997, 71:6582-6592.
46. Saad JS, Miller J, Tai J, Kim A, Ghanam RH, Summers MF: Structural basis for targeting HIV-1 Gag proteins to the plasma membrane for virus assembly. Proc Natl Acad Sci U S A 2006, 103:11364-11369.

47. Briggs JA, Simon MN, Gross I, Krausslich HG, Fuller SD, Vogt VM, Johnson MC: The stoichiometry of Gag protein in HIV-1. Nat Struct Mol Biol 2004, 11:672-675.

48. Morita E, Sundquist Wl: Retrovirus budding. Annu Rev Cell Dev Biol 2004, 20:395-425.

49. Nagashima S, Takahashi M, Jirintai S, Tanaka T, Nishizawa T, Yasuda J, Okamoto H: Tumour susceptibility gene 101 and the vacuolar protein sorting pathway are required for the release of hepatitis E virions. J Gen Virol 2011, 92:2838-2848.

50. Garrus JE, von Schwedler UK, Pornillos OW, Morham SG, Zavitz KH, Wang HE, Wettstein DA, Stray KM, Cote M, Rich RL, et al: Tsg101 and the vacuolar protein sorting pathway are essential for HIV-1 budding. Cell 2001, 107:55-65.

51. VerPlank L, Bouamr F, LaGrassa TJ, Agresta B, Kikonyogo A, Leis J, Carter CA: Tsg101, a homologue of ubiquitin-conjugating (E2) enzymes, binds the $L$ domain in HIV type 1 Pr55(Gag). Proc Natl Acad Sci U S A 2001, 98:7724-7729.

52. Martin-Serrano J, Zang T, Bieniasz PD: HIV-1 and Ebola virus encode small peptide motifs that recruit Tsg101 to sites of particle assembly to facilitate egress. Nat Med 2001, 7:1313-1319.

53. Demirov DG, Ono A, Orenstein JM, Freed EO: Overexpression of the $\mathrm{N}$-terminal domain of TSG101 inhibits HIV-1 budding by blocking late domain function. Proc Natl Acad Sci U S A 2002, 99:955-960.

54. Puffer BA, Parent LJ, Wills JW, Montelaro RC: Equine infectious anemia virus utilizes a YXXL motif within the late assembly domain of the Gag p9 protein. J Virol 1997, 71:6541-6546.

55. Strack B, Calistri A, Craig S, Popova E, Gottlinger HG: AIP1/ALIX is a binding partner for HIV-1 p6 and EIAV p9 functioning in virus budding. Cell 2003, 114:689-699.

56. Dilley KA, Gregory D, Johnson MC, Vogt VM: An LYPSL late domain in the gag protein contributes to the efficient release and replication of Rous sarcoma virus. J Virol 2010, 84:6276-6287.

57. Zhai Q, Fisher RD, Chung HY, Myszka DG, Sundquist WI, Hill CP: Structural and functional studies of ALIX interactions with YPX(n)L late domains of HIV-1 and EIAV. Nat Struct Mol Biol 2008, 15:43-49.

58. Yuan B, Campbell S, Bacharach E, Rein A, Goff SP: Infectivity of Moloney murine leukemia virus defective in late assembly events is restored by late assembly domains of other retroviruses. J Virol 2000, 74:7250-7260.

59. Martin-Serrano J, Eastman SW, Chung W, Bieniasz PD: HECT ubiquitin ligases link viral and cellular PPXY motifs to the vacuolar protein-sorting pathway. J Cell Biol 2005, 168:89-101.

60. Xiang Y, Cameron CE, Wills JW, Leis J: Fine mapping and characterization of the Rous sarcoma virus Pr76gag late assembly domain. J Virol 1996, 70:5695-5700.

61. Parent LJ, Bennett RP, Craven RC, Nelle TD, Krishna NK, Bowzard JB, Wilson CB, Puffer BA, Montelaro RC, Wills JW: Positionally independent and exchangeable late budding functions of the Rous sarcoma virus and human immunodeficiency virus Gag proteins. J Virol 1995, 69:5455-5460.

62. Wills JW, Cameron CE, Wilson CB, Xiang Y, Bennett RP, Leis J: An assembly domain of the Rous sarcoma virus Gag protein required late in budding. J Virol 1994, 68:6605-6618.

63. Gottwein E, Bodem J, Muller B, Schmechel A, Zentgraf H, Krausslich HG: The Mason-Pfizer monkey virus PPPY and PSAP motifs both contribute to virus release. J Virol 2003, 77:9474-9485.

64. Yasuda J, Hunter E, Nakao M, Shida H: Functional involvement of a novel Nedd4-like ubiquitin ligase on retrovirus budding. EMBO Rep 2002, 3:636-640.

65. Bouamr F, Melillo JA, Wang MQ: Nagashima K, de Los Santos M, Rein A, Goff SP: PPPYVEPTAP motif is the late domain of human T-cell leukemia virus type $1 \mathrm{Gag}$ and mediates its functional interaction with cellular proteins Nedd4 and Tsg101 [corrected]. J Virol 2003, 77:11882-11895.

66. Heidecker G, Lloyd PA, Fox K, Nagashima K, Derse D: Late assembly motifs of human T-cell leukemia virus type 1 and their relative roles in particle release. J Virol 2004, 78:6636-6648.

67. Le Blanc I, Prevost MC, Dokhelar MC, Rosenberg AR: The PPPY motif of human T-cell leukemia virus type $1 \mathrm{Gag}$ protein is required early in the budding process. J Virol 2002, 76:10024-10029. 
68. Kikonyogo A, Bouamr F, Vana ML, Xiang Y, Aiyar A, Carter C, Leis J: Proteins related to the Nedd4 family of ubiquitin protein ligases interact with the $\mathrm{L}$ domain of Rous sarcoma virus and are required for gag budding from cells. Proc Natl Acad Sci U S A 2001, 98:11199-11204.

69. Chung HY, Morita E, von Schwedler U, Muller B, Krausslich HG, Sundquist Wl: NEDD4L overexpression rescues the release and infectivity of human immunodeficiency virus type 1 constructs lacking PTAP and YPXL late domains. J Virol 2008, 82:4884-4897.

70. Sette P, Jadwin JA, Dussupt V, Bello NF, Bouamr F: The ESCRT-associated protein Alix recruits the ubiquitin ligase Nedd4-1 to facilitate HIV-1 release through the LYPXnL L domain motif. J Virol 2010, 84:8181-8192.

71. Katzmann DJ, Babst M, Emr SD: Ubiquitin-dependent sorting into the multivesicular body pathway requires the function of a conserved endosomal protein sorting complex. ESCRT-I. Cell 2001, 106:145-155.

72. Raymond CK, Howald-Stevenson I, Vater CA, Stevens TH: Morphological classification of the yeast vacuolar protein sorting mutants: evidence for a prevacuolar compartment in class E vps mutants. Mol Biol Cell 1992, 3:1389-1402.

73. Babst M: A protein's final ESCRT. Traffic 2005, 6:2-9.

74. Carlton JG, Martin-Serrano J: Parallels between cytokinesis and retroviral budding: a role for the ESCRT machinery. Science 2007, 316:1908-1912.

75. Nabhan JF, Hu R, Oh RS, Cohen SN, Lu Q: Formation and release of arrestin domain-containing protein 1-mediated microvesicles (ARMMs) at plasma membrane by recruitment of TSG101 protein. Proc Natl Acad Sci U S A 2012, 109:4146-4151.

76. Baietti MF, Zhang Z, Mortier E, Melchior A, Degeest G, Geeraerts A, Ivarsson Y, Depoortere F, Coomans C, Vermeiren E, et al: Syndecan-syntenin-ALIX regulates the biogenesis of exosomes. Nat Cell Biol 2012, 14:677-685.

77. Dores MR, Chen B, Lin H, Soh UJ, Paing MM, Montagne WA, Meerloo T, Trejo J: ALIX binds a YPX(3)L motif of the GPCR PAR1 and mediates ubiquitinindependent ESCRT-III/MVB sorting. J Cell Biol 2012, 197:407-419.

78. Pornillos O, Higginson DS, Stray KM, Fisher RD, Garrus JE, Payne M, He GP, Wang HE, Morham SG, Sundquist WI: HIV Gag mimics the Tsg101recruiting activity of the human Hrs protein. J Cell Biol 2003, 162:425-434.

79. Brass AL, Dykxhoorn DM, Benita Y, Yan N, Engelman A, Xavier RJ, Lieberman J, Elledge SJ: Identification of host proteins required for HIV infection through a functional genomic screen. Science 2008, 319:921-926.

80. Janvier K, Pelchen-Matthews A, Renaud JB, Caillet M, Marsh M, Berlioz-Torrent C: The ESCRT-0 component HRS is required for HIV-1 Vpu-mediated BST-2/tetherin down-regulation. PLOS Pathog 2011, 7:e1001265.

81. Neil SJ, Zang T, Bieniasz PD: Tetherin inhibits retrovirus release and is antagonized by HIV-1 Vpu. Nature 2008, 451:425-430.

82. Babst M, Odorizzi G, Estepa EJ, Emr SD: Mammalian tumor susceptibility gene 101 (TSG101) and the yeast homologue, Vps23p, both function in late endosomal trafficking. Traffic 2000, 1:248-258

83. Bishop N, Woodman P: TSG101/mammalian VPS23 and mammalian VPS28 interact directly and are recruited to VPS4-induced endosomes. J Biol Chem 2001, 276:11735-11742.

84. Kostelansky MS, Schluter C, Tam YY, Lee S, Ghirlando R, Beach B, Conibear E, Hurley JH: Molecular architecture and functional model of the complete yeast ESCRT-I heterotetramer. Cell 2007, 129:485-498.

85. Pineda-Molina E, Belrhali H, Piefer AJ, Akula I, Bates P, Weissenhorn W: The crystal structure of the C-terminal domain of Vps28 reveals a conserved surface required for Vps20 recruitment. Traffic 2006, 7:1007-1016.

86. Bache KG, Slagsvold T, Cabezas A, Rosendal KR, Raiborg C, Stenmark H: The growth-regulatory protein HCRP1/hVps37A is a subunit of mammalian ESCRT-I and mediates receptor down-regulation. Mol Biol Cell 2004, 15:4337-4346.

87. Stuchell MD, Garrus JE, Muller B, Stray KM, Ghaffarian S, McKinnon R, Krausslich HG, Morham SG, Sundquist WI: The human endosomal sorting complex required for transport (ESCRT-I) and its role in HIV-1 budding. J Biol Chem 2004, 279:36059-36071.

88. Eastman SW, Martin-Serrano J, Chung W, Zang T, Bieniasz PD: Identification of human VPS37C, a component of endosomal sorting complex required for transport-I important for viral budding. J Biol Chem 2005, 280:628-636.

89. Morita E, Sandrin V, Alam SL, Eckert DM, Gygi SP, Sundquist WI: Identification of human MVB12 proteins as ESCRT-I subunits that function in HIV budding. Cell Host Microbe 2007, 2:41-53.

90. Oestreich AJ, Davies BA, Payne JA, Katzmann DJ: Mvb12 is a novel member of ESCRT-I involved in cargo selection by the multivesicular body pathway. Mol Biol Cell 2007, 18:646-657.
91. Boura E, Rozycki B, Herrick DZ, Chung HS, Vecer J, Eaton WA, Cafiso DS, Hummer G, Hurley JH: Solution structure of the ESCRT-I complex by small-angle X-ray scattering, EPR, and FRET spectroscopy. Proc Natl Acad Sci U S A 2011, 108:9437-9442.

92. de Souza RF, Aravind L: UMA and MABP domains throw light on receptor endocytosis and selection of endosomal cargoes. Bioinformatics 2010, 26:1477-1480.

93. Stefani F, Zhang L, Taylor S, Donovan J, Rollinson S, Doyotte A, Brownhill K, Bennion J, Pickering-Brown S, Woodman P: UBAP1 is a component of an endosome-specific ESCRT-I complex that is essential for MVB sorting. Curr Biol 2011, 21:1245-1250.

94. Agromayor M, Soler N, Caballe A, Kueck T, Freund SM, Allen MD, Bycroft M, Perisic O, Ye Y, McDonald B, et al: The UBAP1 subunit of ESCRT-I interacts with ubiquitin via a SOUBA domain. Structure 2012, 20:414-428.

95. Pornillos O, Alam SL, Davis DR, Sundquist WI: Structure of the Tsg101 UEV domain in complex with the PTAP motif of the HIV-1 p6 protein. Nat Struct Biol 2002, 9:812-817.

96. Rauch S, Martin-Serrano J: Multiple interactions between the ESCRT machinery and arrestin-related proteins: implications for PPXY-dependent budding. J Virol 2011, 85:3546-3556.

97. Martin-Serrano J, Zang T, Bieniasz PD: Role of ESCRT-I in retroviral budding. J Virol 2003, 77:4794-4804.

98. Kostelansky MS, Sun J, Lee S, Kim J, Ghirlando R, Hierro A, Emr SD, Hurley $\mathrm{JH}$ : Structural and functional organization of the ESCRT-I trafficking complex. Cell 2006, 125:113-126.

99. Hierro A, Sun J, Rusnak AS, Kim J, Prag G, Emr SD, Hurley JH: Structure of the ESCRT-II endosomal trafficking complex. Nature 2004, 431:221-225.

100. Babst M, Katzmann DJ, Snyder WB, Wendland B, Emr SD: Endosome-associated complex, ESCRT-II, recruits transport machinery for protein sorting at the multivesicular body. Dev Cell 2002, 3:283-289.

101. Williams RL, Urbe S: The emerging shape of the ESCRT machinery. Nat Rev Mol Cell Biol 2007, 8:355-368.

102. Wollert T, Hurley JH: Molecular mechanism of multivesicular body biogenesis by ESCRT complexes. Nature 2010, 464:864-869.

103. Teo H, Gill DJ, Sun J, Perisic O, Veprintsev DB, Vallis Y, Emr SD, Williams RL: ESCRT-I core and ESCRT-II GLUE domain structures reveal role for GLUE in linking to ESCRT-I and membranes. Cell 2006, 125:99-111.

104. Bajorek M, Schubert HL, McCullough J, Langelier C, Eckert DM, Stubblefield WM, Uter NT, Myszka DG, Hill CP, Sundquist WI: Structural basis for ESCRT-III protein autoinhibition. Nat Struct Mol Biol 2009, 16:754-762.

105. Muziol T, Pineda-Molina E, Ravelli RB, Zamborlini A, Usami Y, Gottlinger H, Weissenhorn W: Structural basis for budding by the ESCRT-III factor CHMP3. Dev Cell 2006, 10:821-830.

106. Xiao J, Chen XW, Davies BA, Saltiel AR, Katzmann DJ, Xu Z: Structural basis of Ist1 function and Ist1-Did2 interaction in the multivesicular body pathway and cytokinesis. Mol Biol Cell 2009, 20:3514-3524.

107. Shim S, Kimpler LA, Hanson PI: Structure/function analysis of four core ESCRT-III proteins reveals common regulatory role for extreme C-terminal domain. Traffic 2007, 8:1068-1079.

108. Kieffer C, Skalicky JJ, Morita E, De Domenico I, Ward DM, Kaplan J, Sundquist WI: Two distinct modes of ESCRT-III recognition are required for VPS4 functions in lysosomal protein targeting and HIV-1 budding. Dev Cell 2008, 15:62-73.

109. Obita T, Saksena S, Ghazi-Tabatabai S, Gill DJ, Perisic O, Emr SD, Williams RL: Structural basis for selective recognition of ESCRT-III by the AAA ATPase Vps4. Nature 2007, 449:735-739.

110. Samson RY, Obita T, Freund SM, Williams RL, Bell SD: A role for the ESCRT system in cell division in archaea. Science 2008, 322:1710-1713.

111. Skalicky JJ, Arii J, Wenzel DM, Stubblefield WM, Katsuyama A, Uter NT, Bajorek M, Myszka DG, Sundquist WI: Interactions of the Human LIP5 Regulatory Protein with Endosomal Sorting Complexes Required for Transport. J Biol Chem 2012, 287:43910-43926.

112. Solomons J, Sabin C, Poudevigne E, Usami Y, Hulsik DL, Macheboeuf $P$, Hartlieb B, Gottlinger H, Weissenhorn W: Structural basis for ESCRT-III CHMP3 recruitment of AMSH. Structure 2011, 19:1149-1159.

113. Stuchell-Brereton MD, Skalicky JJ, Kieffer C, Karren MA, Ghaffarian S, Sundquist WI: ESCRT-III recognition by VPS4 ATPases. Nature 2007, 449:740-744.

114. Yang Z, Vild C, Ju J, Zhang X, Liu J, Shen J, Zhao B, Lan W, Gong F, Liu M, et al: Structural basis of molecular recognition between ESCRT-III like protein Vps60 and AAA-ATPase regulator Vta1 in the multi-vesicular body pathway. J Biol Chem 2012, 287:43899-43908. 
115. Scott A, Chung HY, Gonciarz-Swiatek M, Hill GC, Whitby FG, Gaspar J, Holton JM, Viswanathan R, Ghaffarian S, Hill CP, Sundquist WI: Structural and mechanistic studies of VPS4 proteins. EMBO J 2005, 24:3658-3669.

116. Martin-Serrano J, Yarovoy A, Perez-Caballero D, Bieniasz PD: Divergent retroviral late-budding domains recruit vacuolar protein sorting factors by using alternative adaptor proteins. Proc Natl Acad Sci U S A 2003, 100:12414-12419.

117. von Schwedler UK, Stuchell M, Muller B, Ward DM, Chung HY, Morita E, Wang HE, Davis T, He GP, Cimbora DM, et al: The protein network of HIV budding. Cell 2003, 114:701-713.

118. Fisher RD, Chung HY, Zhai Q, Robinson H, Sundquist WI, Hill CP: Structural and biochemical studies of ALIX/AIP1 and its role in retrovirus budding. Cell 2007, 128:841-852.

119. Usami Y, Popov S, Gottlinger HG: Potent rescue of human immunodeficiency virus type 1 late domain mutants by ALIX/AIP1 depends on its CHMP4 binding site. J Virol 2007, 81:6614-6622.

120. Saksena S, Wahlman J, Teis D, Johnson AE, Emr SD: Functional reconstitution of ESCRT-III assembly and disassembly. Cell 2009, 136:97-109.

121. Teis D, Saksena S, Judson BL, Emr SD: ESCRT-II coordinates the assembly of ESCRT-III filaments for cargo sorting and multivesicular body vesicle formation. EMBO J 2010, 29:871-883.

122. Morita E, Sandrin V, McCullough J, Katsuyama A, Baci Hamilton I, Sundquist WI: ESCRT-III protein requirements for HIV-1 budding. Cell Host Microbe 2011, 9:235-242

123. Pires R, Hartlieb B, Signor L, Schoehn G, Lata S, Roessle M, Moriscot C, Popov S, Hinz A, Jamin M, et al: A crescent-shaped ALIX dimer targets ESCRT-III CHMP4 filaments. Structure 2009, 17:843-856.

124. Effantin G, Dordor A, Sandrin V, Martinelli N, Sundquist Wl, Schoehn G, Weissenhorn W: ESCRT-III CHMP2A and CHMP3 form variable helical polymers in vitro and act synergistically during HIV-1 budding. Cell Microbiol 2012, doi:10.1111/cmi.12041.

125. Wollert T, Wunder C, Lippincott-Schwartz J, Hurley JH: Membrane scission by the ESCRT-III complex. Nature 2009, 458:172-177.

126. Hanson PI, Roth R, Lin Y, Heuser JE: Plasma membrane deformation by circular arrays of ESCRT-III protein filaments. J Cell Bio/ 2008, 180:389-402.

127. Ghazi-Tabatabai S, Saksena S, Short JM, Pobbati AV, Veprintsev DB, Crowther RA, Emr SD, Egelman EH, Williams RL: Structure and disassembly of filaments formed by the ESCRT-III subunit Vps24. Structure 2008, 16:1345-1356.

128. Lata S, Schoehn G, Jain A, Pires R, Piehler J, Gottlinger HG, Weissenhorn W: Helical structures of ESCRT-III are disassembled by VPS4. Science 2008, 321:1354-1357.

129. Bodon G, Chassefeyre R, Pernet-Gallay K, Martinelli N, Effantin G, Hulsik DL, Belly A, Goldberg Y, Chatellard-Causse C, Blot B, et al: Charged multivesicular body protein $2 \mathrm{~B}$ (CHMP2B) of the endosomal sorting complex required for transport-III (ESCRT-III) polymerizes into helical structures deforming the plasma membrane. J Biol Chem 2011, 286:40276-40286.

130. Azmi IF, Davies BA, Xiao J, Babst M, Xu Z, Katzmann DJ: ESCRT-III family members stimulate Vps4 ATPase activity directly or via Vta1. Dev Cell 2008, 14:50-61.

131. Dimaano C, Jones CB, Hanono A, Curtiss M, Babst M: Ist1 regulates Vps4 localization and assembly. Mol Biol Cell 2008, 19:465-474.

132. Rue SM, Mattei S, Saksena S, Emr SD: Novel Ist1-Did2 complex functions at a late step in multivesicular body sorting. Mol Biol Cell 2008, 19:475-484.

133. Shestakova A, Hanono A, Drosner S, Curtiss M, Davies BA, Katzmann DJ, Babst M: Assembly of the AAA ATPase Vps4 on ESCRT-III. Mol Biol Cell 2010, 21:1059-1071.

134. Ward DM, Vaughn MB, Shiflett SL, White PL, Pollock AL, Hill J, Schnegelberger R, Sundquist WI, Kaplan J: The role of LIP5 and CHMP5 in multivesicular body formation and HIV-1 budding in mammalian cells. J Biol Chem 2005, 280:10548-10555.

135. Hill CP, Babst M: Structure and function of the membrane deformation AAA ATPase Vps4. Biochim Biophys Acta 2012, 1823:172-181.

136. Scheuring S, Rohricht RA, Schoning-Burkhardt B, Beyer A, Muller S, Abts HF, Kohrer K: Mammalian cells express two VPS4 proteins both of which are involved in intracellular protein trafficking. J Mol Biol 2001, 312:469-480.

137. Babst M, Wendland B, Estepa EJ, Emr SD: The Vps4p AAA ATPase regulates membrane association of a Vps protein complex required for normal endosome function. EMBO J 1998, 17:2982-2993.
138. Azmi I, Davies B, Dimaano C, Payne J, Eckert D, Babst M, Katzmann DJ: Recycling of ESCRTs by the AAA-ATPase Vps4 is regulated by a conserved VSL region in Vta1. J Cell Biol 2006, 172:705-717.

139. Yang D, Hurley JH: Structural role of the Vps4-Vta1 interface in ESCRT-III recycling. Structure 2010, 18:976-984.

140. Gonciarz MD, Whitby FG, Eckert DM, Kieffer C, Heroux A, Sundquist WI, Hill CP. Biochemical and structural studies of yeast Vps4 oligomerization. $J \mathrm{Mol}$ Biol 2008, 384:878-895.

141. Yu Z, Gonciarz MD, Sundquist WI, Hill CP, Jensen GJ: Cryo-EM structure of dodecameric Vps4p and its 2:1 complex with Vta1p. J Mol Biol 2008, 377:364-377.

142. Elia N, Sougrat R, Spurlin TA, Hurley JH, Lippincott-Schwartz J: Dynamics of endosomal sorting complex required for transport (ESCRT) machinery during cytokinesis and its role in abscission. Proc Natl Acad Sci U S A 2011, 108:4846-4851.

143. Jouvenet N, Zhadina M, Bieniasz PD, Simon SM: Dynamics of ESCRT protein recruitment during retroviral assembly. Nat Cell Biol 2011, 13:394-401.

144. Baumgartel V, Ivanchenko S, Dupont A, Sergeev M, Wiseman PW, Krausslich HG, Brauchle C, Muller B, Lamb DC: Live-cell visualization of dynamics of HIV budding site interactions with an ESCRT component. Nat Cell Bio/ 2011, 13:469-474.

145. Fabrikant G, Lata S, Riches JD, Briggs JA, Weissenhorn W, Kozlov MM: Computational model of membrane fission catalyzed by ESCRT-III. PLOS Comput Biol 2009, 5:e1000575.

146. Usami Y, Popov S, Weiss ER, Vriesema-Magnuson C, Calistri A, Gottlinger HG: Regulation of CHMP4/ESCRT-III function in human immunodeficiency virus type 1 budding by CC2D1A. J Virol 2012, 86:3746-3756.

147. Martinelli N, Hartlieb B, Usami Y, Sabin C, Dordor A, Miguet N, Avilov SV, Ribeiro EA Jr, Gottlinger H, Weissenhorn W: CC2D1A is a regulator of ESCRT-III CHMP4B. J Mol Biol 2012, 419:75-88.

148. Fyfe I, Schuh AL, Edwardson JM, Audhya A: Association of the endosomal sorting complex ESCRT-II with the Vps20 subunit of ESCRT-III generates a curvature-sensitive complex capable of nucleating ESCRT-III filaments. J Biol Chem 2011, 286:34262-34270.

149. Odorizzi G, Katzmann DJ, Babst M, Audhya A, Emr SD: Bro1 is an endosome-associated protein that functions in the MVB pathway in Saccharomyces cerevisiae. J Cell Sci 2003, 116:1893-1903.

150. Martin-Serrano J, Bieniasz PD: A bipartite late-budding domain in human immunodeficiency virus type 1. J Virol 2003, 77:12373-12377.

151. Lee S, Joshi A, Nagashima K, Freed EO, Hurley JH: Structural basis for viral late-domain binding to Alix. Nat Struct Mol Biol 2007, 14:194-199.

152. Dowlatshahi DP, Sandrin V, Vivona S, Shaler TA, Kaiser SE, Melandri F, Sundquist WI, Kopito RR: ALIX Is a Lys63-Specific Polyubiquitin Binding Protein that Functions in Retrovirus Budding. Dev Cell 2012, 23:1247-1254

153. Fujii K, Hurley JH, Freed EO: Beyond Tsg101: the role of Alix in 'ESCRTing' HIV-1. Nat Rev Microbiol 2007, 5:912-916.

154. Odorizzi G: The multiple personalities of Alix. J Cell Sci 2006, 119:3025-3032.

155. Munshi UM, Kim J, Nagashima K, Hurley JH, Freed EO: An Alix fragment potently inhibits HIV-1 budding: characterization of binding to retroviral YPXL late domains. J Biol Chem 2007, 282:3847-3855.

156. Carlton JG, Agromayor M, Martin-Serrano J: Differential requirements for Alix and ESCRT-III in cytokinesis and HIV-1 release. Proc Natl Acad SCI U S A 2008, 105:10541-10546.

157. Zhai Q, Landesman MB, Chung HY, Dierkers A, Jeffries CM, Trewhella J, Hill CP, Sundquist WI: Activation of the retroviral budding factor ALIX. $J$ Virol 2011, 85:9222-9226.

158. Kim J, Sitaraman S, Hierro A, Beach BM, Odorizzi G, Hurley JH: Structural basis for endosomal targeting by the Bro1 domain. Dev Cell 2005, 8:937-947

159. McCullough J, Fisher RD, Whitby FG, Sundquist WI, Hill CP: ALIX-CHMP4 interactions in the human ESCRT pathway. Proc Natl Acad Sci U S A 2008 105:7687-7691.

160. Dussupt V, Javid MP, Abou-Jaoude G, Jadwin JA, de La Cruz J, Nagashima K, Bouamr F: The nucleocapsid region of HIV-1 Gag cooperates with the PTAP and LYPXnL late domains to recruit the cellular machinery necessary for viral budding. PLoS Pathog 2009, 5:e1000339.

161. Popov S, Popova E, Inoue M, Gottlinger HG: Human immunodeficiency virus type $1 \mathrm{Gag}$ engages the Bro1 domain of ALIX/AIP1 through the nucleocapsid. J Virol 2008, 82:1389-1398. 

site in Alix is autoinhibited as revealed by a conformation-sensitive anti-Alix monoclonal antibody. Biochem J 2008, 414:215-220.

163. Zhou X, Si J, Corvera J, Gallick GE, Kuang J: Decoding the intrinsic mechanism that prohibits ALIX interaction with ESCRT and viral proteins. Biochem J 2010, 432:525-534.

164. Dunn R, Klos DA, Adler AS, Hicke L: The C2 domain of the Rsp5 ubiquitin ligase binds membrane phosphoinositides and directs ubiquitination of endosomal cargo. J Cell Biol 2004, 165:135-144.

165. Usami Y, Popov S, Popova E, Gottlinger HG: Efficient and specific rescue of human immunodeficiency virus type 1 budding defects by a Nedd4-like ubiquitin ligase. J Virol 2008, 82:4898-4907.

166. Itani OA, Campbell JR, Herrero J, Snyder PM, Thomas CP: Alternate promoters and variable splicing lead to hNedd4-2 isoforms with a C2 domain and varying number of WW domains. Am J Physiol Renal Physio 2003, 285:F916-929.

167. Weiss ER, Popova E, Yamanaka H, Kim HC, Huibregtse JM, Gottlinger H: Rescue of HIV-1 release by targeting widely divergent NEDD4-type ubiquitin ligases and isolated catalytic HECT domains to Gag. PLoS Pathog 2010, 6:e1001107.

168. Cimarelli A, Sandin S, Hoglund S, Luban J: Basic residues in human immunodeficiency virus type 1 nucleocapsid promote virion assembly via interaction with RNA. J Virol 2000, 74:3046-3057.

169. Muriaux D, Mirro J, Nagashima K, Harvin D, Rein A: Murine leukemia virus nucleocapsid mutant particles lacking viral RNA encapsidate ribosomes J Virol 2002, 76:11405-11413.

170. Zhang Y, Qian H, Love Z, Barklis E: Analysis of the assembly function of the human immunodeficiency virus type 1 gag protein nucleocapsid domain. J Virol 1998, 72:1782-1789.

171. Alfadhli A, Dhenub TC, Still A, Barklis E: Analysis of human immunodeficiency virus type 1 Gag dimerization-induced assembly. J Virol 2005, 79:14498-14506.

172. Zhang H, Curreli F, Zhang X, Bhattacharya S, Waheed AA, Cooper A, Cowburn D, Freed EO, Debnath AK: Antiviral activity of alpha-helical stapled peptides designed from the HIV-1 capsid dimerization domain. Retrovirology 2011, 8:28,

173. Llewellyn GN, Hogue IB, Grover JR, Ono A: Nucleocapsid promotes localization of HIV-1 gag to uropods that participate in virological synapses between T cells. PLoS Pathog 2010, 6:e1001167.

174. Ganser-Pornillos BK, Cheng A, Yeager M: Structure of full-length HIV-1 CA: a model for the mature capsid lattice. Cell 2007, 131:70-79.

175. Li S, Hill CP, Sundquist WI, Finch JT: Image reconstructions of helical assemblies of the HIV-1 CA protein. Nature 2000, 407:409-413.

176. Pornillos O, Ganser-Pornillos BK, Kelly BN, Hua Y, Whitby FG, Stout CD, Sundquist $\mathrm{Wl}$, Hill CP, Yeager M: X-ray structures of the hexameric building block of the HIV capsid. Cell 2009, 137:1282-1292.

177. Popov S, Strack B, Sanchez-Merino V, Popova E, Rosin H, Gottlinger HG: Human immunodeficiency virus type 1 and related primate lentiviruses engage clathrin through Gag-Pol or Gag. J Virol 2011, 85:3792-3801.

178. Zhang F, Zang T, Wilson SJ, Johnson MC, Bieniasz PD: Clathrin facilitates the morphogenesis of retrovirus particles. PLOS Pathog 2011, 7:e1002119.

179. Liang C, Rong L, Cherry E, Kleiman L, Laughrea M, Wainberg MA: Deletion mutagenesis within the dimerization initiation site of human immunodeficiency virus type 1 results in delayed processing of the $\mathrm{p} 2$ peptide from precursor proteins. J Virol 1999, 73:6147-6151.

180. L'Hernault A, Weiss EU, Greatorex JS, Lever AM: HIV-2 genome dimerization is required for the correct processing of Gag: a second-site reversion in matrix can restore both processes in dimerization-impaired mutant viruses. J Virol 2012, 86:5867-5876.

181. Shehu-Xhilaga M, Kraeusslich HG, Pettit S, Swanstrom R, Lee JY, Marshall JA, Crowe SM, Mak J: Proteolytic processing of the p2/nucleocapsid cleavage site is critical for human immunodeficiency virus type 1 RNA dimer maturation. J Virol 2001, 75:9156-9164.

182. Liang C, Rong L, Laughrea M, Kleiman L, Wainberg MA: Compensatory point mutations in the human immunodeficiency virus type $1 \mathrm{Gag}$ region that are distal from deletion mutations in the dimerization initiation site can restore viral replication. J Virol 1998, 72:6629-6636.

doi:10.1186/1742-4690-10-5

Cite this article as: Meng and Lever: Wrapping up the bad news - HIV assembly and release. Retrovirology 2013 10:5.

\section{Submit your next manuscript to BioMed Central and take full advantage of:}

- Convenient online submission

- Thorough peer review

- No space constraints or color figure charges

- Immediate publication on acceptance

- Inclusion in PubMed, CAS, Scopus and Google Scholar

- Research which is freely available for redistribution 